\title{
Relations between Russia and Turkey Before, During, and After the Failed Coup of 2016
}

\author{
ŞENER AKTÜRK ${ }^{*}$
}

ABSTRACT Increasing cooperation between Russia and Turkey date back to the 1990s, and go beyond the preferences of a specific political party or leader. A number of geopolitical interests pitted Russia and Turkey against one another in neighboring regions. The escalation of PKK attacks in Turkey starting in July 2015 and the failed coup attempt of the Gülenists in July 2016 motivated Turkey to seek closer relations with Russia as the United States became an increasingly unreliable actor in the context of Turkey's fight against the PKK-PYD and the Gülenists. Likewise, Russia's dependence on the Turkish Straits as its main supply route to its bases in Syria, Turkey's role as a key customer of Russian natural gas and grain, the goal of breaching Western economic sanctions, as well as consolidating Russia's internal security, all motivate Russia to seek closer relations with Turkey.

\section{Introduction}

he foundations of increasing cooperation between Russia and Turkey in the 2010s date back to the 1990s, and hence transcend the idiosyncratic choices or contingent preferences of a specific political party or political leader such as presidents Vladimir Putin and Recep Tayyip Erdoğan in Russia and Turkey, respectively. Seismic geopolitical shifts that motivate Russian-Turkish rapprochment were already underway with the end of the Cold War. ${ }^{1}$ However, a number of seemingly incompatible geopolitical interests pitted Russia and Turkey against one another in the Balkans, the Caucasus, and the Middle East. ${ }^{2}$ While 1999 provided the first significant turning point for increased cooperation since the end of the Cold War, when Russia refused PKK leader Abdullah Öcalan's request for political asylum in Moscow, despite Duma's almost unanimous approval, ${ }^{3}$ the failed coup of 2016 seems to have provided another turning point for the elevation of bilateral cooperation between Russia and Turkey. The launching of an all out offensive by the PKK against Turkey in July 2015, ${ }^{4}$ and the coup attempt by the Gülenists in July 2016, combined with the explicit support and shelter provided by the United States

* Koç University, Turkey 


\section{Despite the occassional flare up of contentious issues that seem to fracture bilateral relations in the short run, Russia and Turkey have been able to repair the damage and maintain a high level of cooperation}

(U.S.) to the PYD and the Gülenists, respectively, motivated Turkey to seek closer relations with Russia. In contrast, the United States became increasingly unreliable if not obstructive and hostile in the context of Turkey's fight against the PKKPYD and the Gülenists. ${ }^{5}$ I argue that this is a case of military-strategic considerations regarding internal security outweighing any other causal factor in explaining the improvement of Turkish-Russian relations in 2016, and this argument about internal threats exceeding external threats also constitutes the original contribution of the current article to the scholarly literature. By seeking closer cooperation with Russia, Turkey in effect was "balancing" against two major internal threats, both of which were increasingly perceived as proxies of other great powers, including the greatest military power in the international system, namely, the United States. Such diversification of Turkey's alliance portfolio is not entirely new either, as the current article will explain, and as some other scholars also pointed out. ${ }^{6}$ Likewise, Russia's dependence on the Turkish Straits as the main supply route to its Syrian bases, ${ }^{7}$ its need for Turkey's assistance for a durable new status quo in Syria, Turkey's role as a key customer of Russian natural gas, and the Russian-Turkish nuclear power plant construction by the Mediterranean, all motivate Russia to seek closer relations with Turkey.

Military-strategic, economic, ${ }^{8}$ ideational, ${ }^{9}$ as well as more idiosyncratic factors have been invoked to explain conflict and cooperation between Russia and Turkey over the centuries, including after the Cold War. The two countries' similar status as the "outsider" neighbors whose proximate exclusion has been employed to forge a common European identity is also noteworthy. ${ }^{10}$ Early on in the 1990s, some scholars argued that Turkey and Russia have competing geopolitical interests that are only moderated by their common economic interests, hence juxtaposing the "geopolitical" and the "economic" imperatives as implying opposite trajectories. ${ }^{11}$ Moreover, the asymmetrical nature of Russian-Turkish economic relations are often highlighted, sometimes to explicitly claim that Turkey is dependent on Russia, but what is commonly overlooked in these assessments is the fact that Russia is critically dependent on the export revenue from a few items such as oil, natural gas, grain, and arms, and Turkey became a key customer of Russia in terms of the latter three. While Turkish import of Russian natural gas and weapons (e.g., S-400s) are very well known and extensively discussed in both scholarship and popular media, the fact that "Turkey replaced Egypt as the largest purchaser of Russian grain" in 2017, making Russia the largest exporter of grain in the world, ahead of the United States, 


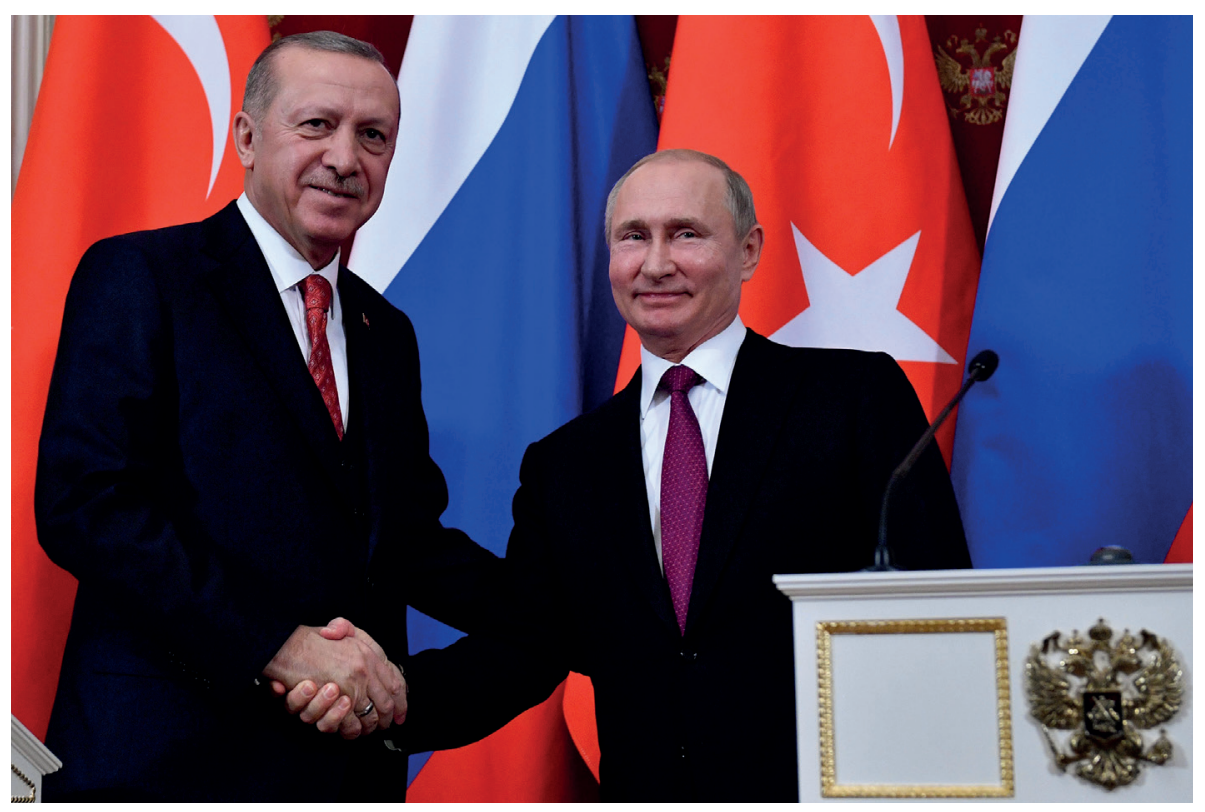

is not noted nearly as much. ${ }^{12}$ In short, economic ties with Turkey are also critical for Russia, especially at a time when the Russian economy is squeezed by Western sanctions and real incomes continued to fall "for the fifth year in a row" in 2018. ${ }^{13}$ Moreover, as Peter Katzenstein and Nicole Weygandt argue, "the insularity of Russia's geopolitical and civilizational approaches limits its foreign policies," ${ }^{14}$ which has arguably benefited and favored Turkey in various ways. In contrast to these depictions, the dissolution of the Soviet Union gave rise to a very powerful geopolitical dynamic in favor of Russian-Turkish cooperation. In short, the rapid decline of the Soviet/Russian threat, epitomized in the disappearance of a land border between post-Soviet Russia and Turkey, opened up multiple avenues for bilateral cooperation. ${ }^{15}$

\section{Vacillations of Cooperation and Conflict between Unstable Governments, 1992-2002}

The first decade after the Cold War witnessed radical vacillations of cooperation and conflict in the bilateral relations between Russia and Turkey, which had coincided with numerous short-lived coalition governments in Turkey and the tumultuous two terms of Yeltsin's presidency with different prime ministers in Russia. While the two countries came to the brink of war through their involvement in the Azerbaijani-Armenian conflict over Nagorno Karabagh in May 1992, ${ }^{16}$ only a decade later, in March 2002, the secretary general of Turkey's National Security Council General Tuncer Kılınç proposed to form
Russian President Vladimir Putin and his Turkish counterpart Recep Tayyip Erdoğan held a joint press conference following their meeting at the Kremlin in Moscow on January 23, 2019.

Alexander Nemenov / AFP / Getty Images 
The geopolitical identity of the Gülenists as a staunchly pro-American faction is directly related to the improvement of Turkish-Russian relations after the failure of the coup attempt an "alliance" with Russia and Iran in the face of hostility from the European Union (EU) member states. ${ }^{17}$

These radical swings were indicative of two long-term trends that characterize Russian-Turkish relations since the end of the Cold War to the present-day: First, they were indicative of the issue-specific variation in relations, such that Russia and Turkey may tend to (and often do) support opposite parties in active military conflicts such as in the Azerbaijani-Armenian, Bosnian, and Syrian conflicts, while in other critical issues such as opposing the U.S. invasion of Iraq or pushing against the U.S.-supported Kurdish socialist (PYD) militants in Syria, they readily cooperate. Second, as their bilateral relations intensify, the number of issues on which Russia and Turkey are unexpectedly confronting each other for the first time lead to exposures of divergent preferences that were hitherto dormant. This has been demonstrated time and again over various conflicts in the past, and it may well happen again in the future over other dormant issues or frozen conflicts that may flare up. An important lesson to draw from past experiences, however, is that despite the occassional flare up of contentious issues that seem to fracture bilateral relations in the short run, Russia and Turkey have been able to repair the damage and maintain a high level of cooperation despite major disagreements. This may be a testimony to the more critical causes of their cooperation that allow the two countries to work together despite their differences.

\section{The Puzzle of Russian-Turkish Rapprochement after 2016}

The scholarly studies of the failed coup in Turkey on July 15, 2016 are still in their infancy. ${ }^{18}$ As for the long-term causes of the coup, the present author has emphasized the existential threat that the decriminalization of Islamic religious practices in public posed for the messianic Gülenist cult that relied on the prohibition and suppression of Islamic religious expression for recruitment and legitimacy, ${ }^{19}$ while some other scholars have emphasized the "inter-security dilemma" between the Gülenists and the AK Party as the primary cause of the coup. ${ }^{20}$ Among many other shortcomings of the extant literature, the international dimension of the military coup has not so far been systematically investigated in English-language academic publications, and in most publications the geopolitical dimension is altogether neglected. In seeking to explain the improvement in Russian-Turkish relations after the coup, this article aims to describe, however briefly, the geopolitical identity and func- 
tion of the Gülenists, and thus, the geopolitical implications of the failure of their attempted coup in 2016, precisely because the geopolitical identity of the Gülenists as a staunchly pro-American faction is directly related to the improvement of Turkish-Russian relations after the failure of the coup attempt.

More importantly for the purposes of the current article, there are almost no publications that primarily and specifically focus on the role of the failed coup in relation to the improvement in Russian-Turkish relations. ${ }^{21}$ Economic, ideational, and military-strategic factors were also invoked in explaining the phenomenal increase in bilateral cooperation between Russia and Turkey after the coup attempt on July 2016. Mamedov and Lukyanov emphasize "four main issues," namely, "terrorism, nuclear weapons, the Syrian crisis and the region's security architecture," and yet it is clear that even among these four main issues, Russia and Turkey have very different interests (i.e., opposite proxies in the Syrian war, and divergent views on NATO expansion) that they pursue at the expense of each other if and whenever necessary. ${ }^{22}$ Moreover, it is unclear what kind of radical change(s) in any of these four main issues motivated Russian-Turkish rapprochement after 2016. Likewise, Pavel Shlykov in his recent evaluation of Russian-Turkish relations in the wider Black Sea region emphasizes that "competiton [between Russia and Turkey] is equally strong," ${ }^{23}$ while Ostap Kushnir argues that the "emergence of the Ukrainian-Turkish geopolitical linchpin is of key importance for the stabilization -in the long run- of the Black Sea regional policies." ${ }^{24}$ The interests of Russia and Turkey in these issue areas did not change radically around 2016, and thus do not correlate with the momentous Russian-Turkish rapprochment starting in 2016. Furthermore, the Russian-Turkish rapprochment began earlier than the coup attempt, and this perceptible change in bilateral relations became public already by June $2016 .{ }^{25}$

As will be argued below, military-strategic considerations far outweighed any other causal factors in the improvement of Turkish-Russian relations in 2016. Less than a year before the failed coup, in November 24, 2015, Turkish-Russian relations hit their nadir when Turkey shot down the Russian SU-24 bomber aircraft along the Turkish-Syrian border for violating Turkish airspace. This incident was also the culmination of a geopolitical escalation between the two countries, primarily driven by Russia's military incursions into and occupation of parts of Georgia in 2008, Ukraine in 2014, and Syria in $2015 .{ }^{26}$ As a result, by the last quarter of 2015, Turkey was surrounded by the Russian occupation forces and/or military reinforcements in the north (Crimea), east (Georgian regions of Abkhazia and South Ossetia), and south (Syria). As such, one could easily posit that the potential external threat from Russia to Turkey peaked by the end of 2015. Against this background, Russian-Turkish rapprochement in 2016 at first appears to be a paramount puzzle, even from a military-strategic point of view. 
Following the downing of the Russian SU-24 bomber aircraft, Russia increased its support to the PYD, the Syrian branch of the PKK, which is recognized as a terrorist organization by the EU, the United States, and Turkey, but significantly enough, not by Russia. This led to the speculation, best exemplified by Princeton historian Michael Reynolds' article asking whether Putin will be "the 'Liberator Tsar' of the Kurds." ${ }^{27}$ What Reynolds and most other Western observers meant with the ethnonym "Kurds" were the Kurdish socialist factions affiliated with the PKK, which is only a subset and furthermore a small minority within the Kurdish populations in Syria, Turkey, and Iraq, as he clarified later in an opinion column with Michael Doran on Turkey's Operation Peace Spring in October 2019. ${ }^{28}$ Reynolds acknowledged that "both the HDP [in Turkey] and Syria's PYD are offshoots of the Kurdistan Workers' Party (PKK)," 29 which is designated as a terrorist organization not only by Turkey but also by the United States. Against the backdrop of such a deep crisis, almost certainly the worst in Russian-Turkish relations since the Cold War, and the accumulated weight of potential external threats posed by recent Russian military incursions in Georgia, Ukraine (especially Crimea), and Syria, what explains the rapid improvement in bilateral relations shortly thereafter in 2016 ?

\section{PKK, PYD, Gülenists, and the Failed Coup: Internal Threats Surpass External Threats}

For Turkey between July 2015 and July 2016, the magnitude of active internal threats, namely, the PKK and the Gülenists, far surpassed any potential external threats, including Russian military buildup in Crimea and Syria, among others, and this radical change in the immediate threat environment is the primary cause of rapid Russian-Turkish rapprochement that began in 2016. This is also a military-strategic consideration, albeit regarding a security threat emanating from a non-state armed group supported by external patrons as in a proxy war setting. Between July 2015 and July 2016, PKK attacks, which included suicide attacks in major city centers such as Istanbul, ${ }^{30}$ killed hundreds of people ${ }^{31}$ including many civilians. Although PYD received Russian support especially after Turkey shot down a Russian bomber aircraft in November 2015, the main supplier of weapons and international political support for the PYD came from the United States. In fact, U.S. troops were eventually deployed to the PYD occupied territories in northeastern Syria in order to protect the PYD zone, among other threats, from a possible operation by Turkey. The strong association between the PKK, the PYD, and the United States already stigmatized the latter as the chief foreign sponsor of the most deadly terrorist organization active within Turkey even before the coup, but it should be emphasized that this association became particulary damaging only after the PKK restarted its attacks on a massive scale within Turkey in July $2015 .^{32}$ 
The coup attempt led by Gülenist officers in 2016 was arguably the most critical and negative turning point in Turkish-American relations in more than a decade. Their leader, Fetullah Gülen, along with many other high-ranking fugitive Gülenists have been living in the United States despite Turkey's requests for extradition, and the Gülenists are widely perceived as the fifth column of the American "deep state" (i.e., Central Intelligence Agency-CIA) by the Turkish military and political elites. ${ }^{33}$

Parallel to their unswerving pro-American geopolitical self-identification, which stoked Turkish concerns regarding their ultimate loyalty, Gülenists were also well-known for their hardline anti-Russian and anti-Iranian stance in foreign policy. Therefore,

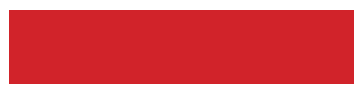

The reaction of the U.S. political leadership and policy community to the coup attempt in Turkey on the night of July 15, 2016, was deeply disappointing, if not offensive, for many Turks the geopolitical identity of Gülenists as such is directly relevant to the further improvement of Russian-Turkish relations after the coup attempt. Gülenists often smeared their opponents, including leading cadres of the AK Party, as "Persians" or "servants of Persians" ("Acem uşaklari") through their numerous social media accounts on YouTube and Twitter especially in the late 2013 and early 2014 when they ratcheted up their criticisms to bring down the Erdoğan government. Likewise, Gülenists were also distinctive among Islamic groups in Turkey in espousing openly right-wing pro-Israeli views, as they demonstrated in the aftermath of the infamous attack on the "Gaza Freedom Flotilla," that was seeking to break the Israeli blockade on Gaza. The Israeli military killed nine activists on board the Mavi Marmara in international waters, and yet, Gülen spoke to The Wall Street Journal after the incident, berating the activists for not seeking the permission of the authorities, by which he meant the Israeli state, if they wanted to help the Palestinians in Gaza. ${ }^{34}$ Gülenists also blamed the Muslim Brotherhood for what went wrong during the Arab Spring in Egypt in particular, implicitly justifying the military coup in Egypt due to the mistakes that the late president Morsi committed before the coup.

It is against the backdrop of their consistently pro-American geopolitical stances supportive of right-wing military authoritarianism that the meteoric growth of Gülenism after the 1980s was linked to the support provided by the U.S. and Turkish governments, especially during and after the military dictatorship of 1980-1983, which in itself is often recognized as the most unabashedly pro-American military dictatorship in Turkish history. Unlike many socialist and Islamist leaders, Gülen was not arrested after the 1980 military coup, and he openly thanked the putschist generals and endorsed the 1980 military coup in his magazine Sızıntı. ${ }^{35}$ In short, Gülenism was considered by many among the Turkish elites as the quintessential pro-American, anti-Rus- 


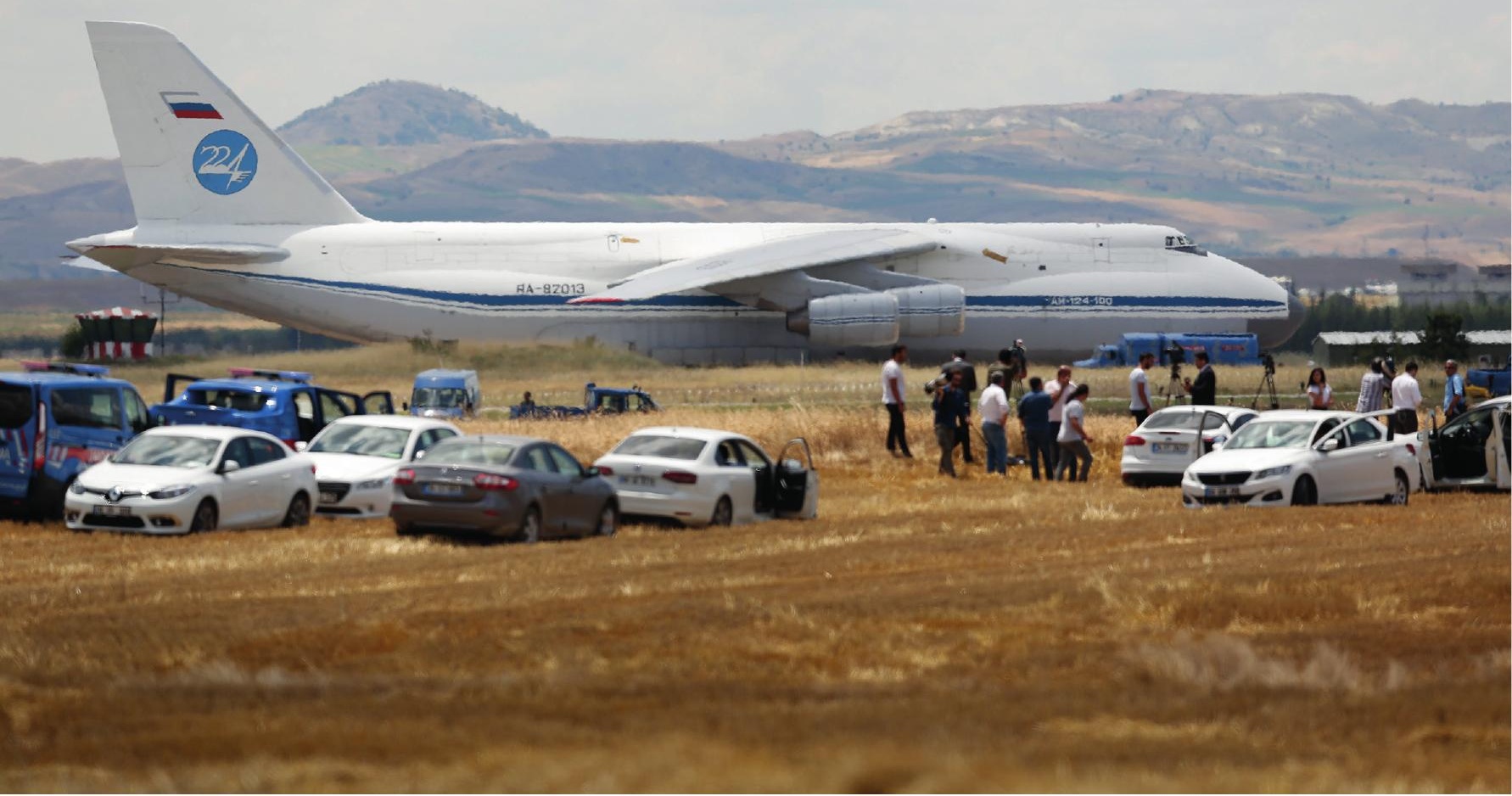

A Russian AN-124

cargo plane

transporting

parts of the

S-400 air defense

system from

Russia landed at

Mürted Airfield

on July 12, 2019

in Ankara, Turkey.

MUSTAFA KIRAZLI/

Getty Images

sian, and anti-Iranian movement during and after the Cold War, and this had immediate repercussions for Russian-Turkish relations after the failure of the Gülenists' coup attempt.

The reaction of the U.S. political leadership and policy community to the coup attempt in Turkey on the night of July 15, 2016, was deeply disappointing, if not offensive, for many Turks. Instead of a swift and unequivocal condemnation of the coup attempt and a call for solidarity with the democratically elected civilian government in Turkey, U.S. officials waited for about four hours after the coup attempt took off. Even worse, in the first official statement coming from a high profile U.S. official, Secretary of State John Kerry expressed his hope that "there will be stability and peace and continuity within Turkey," an extremely ambiguous formulation that neither condemned the coup nor expressed support for the civilian government. ${ }^{36}$ Many other leading figures in the policy community expressed their opinions much earlier, condoning the coup attempt as the lesser of two evils. Chief among them was Richard N. Haass, who has been the president, since 2003, of the prestigious Council on Foreign Relations (CFR), which also publishes the influential journal Foreign Affairs. In an infamous tweet, Haass argued that, "Turkey coup presents dilemma to US, Europe govts: do you support non-democratic coup vs increasingly non-democratic authoritarian leader?" ${ }^{37}$ The odious connotation of this statement was almost immediately pointed out to Haass and he was challenged by many English-speaking Turks, including the current author, who maintained that there is "no dilemma here: you must support the democratically 


\section{After the coup, Russia under Putin was perceived as a most reliable major foreign power supportive of Turkey's fight against the Gülenists}

elected government instead of a military dictatorship." ${ }^{38}$ Not only that Haass did not apologize for his stance during or after the night of the attempted coup, but he retained his prestigious position leading the CFR, and was even seriously considered as a candidate for the position of Deputy Secretary of State in the president-elect Donald Trump's new administration taking shape in late 2016. ${ }^{39}$ Numerous leading Western publications, from The New York Times in the United States to The Economist in the United Kingdom and Der Spiegel in Germany, published news stories that whitewashed the coup attempt and disparaged the civilians who mobilized against the coup plotters and successfully defended democracy. ${ }^{40}$

Against the background of the long-term U.S. support to the Gülenists and the ambivalent, if not pro-coup, statements coming from U.S. elites during and after the coup attempt, the fact that the Gülenist organizations were outlawed and expelled from Russia under Putin already in the early 2000s was prominently highlighted as another indication of the reliability and solidarity of Russia in Turkey's struggle against Gülenists. ${ }^{41}$ Thus, in an ironic reversal of a historic pattern in Turkey, being pro-Russian in foreign policy came to be seen as a sign of being more loyal and patriotic compared to those holding pro-American views, some of whom were suspected of being clandestine Gülenists. Putin publicly warned the Turkish government as early as in 2004 about the Gülenists being behind "coup attempts" and turmoil in several Central Asian republics. ${ }^{42}$ There were even claims in mainstream Turkish media, although ultimately unsubstantiated, that Putin warned the Turkish government ahead of the coup attempt, thus making it possible to defeat the coup plotters. ${ }^{43}$ Despite the unconvincing and unsubstantiated nature of these rumors, Putin was correctly recognized as the first major foreign leader to call the Turkish president in a gesture of support the day after the coup. ${ }^{44}$ Russia under Putin was perceived as a most reliable major foreign power supportive of Turkey's fight against the Gülenists, designated as a terrorist entity with the acronym FETÖ under Turkish law.

As a critical aside problematizing the popular perception of Russia as the most reliable great power partner in Turkey's struggle against Gülenists, one should also note that during the nadir of Turkish-Russian relations after Turkey's shooting down of the SU-24 aircraft bomber, an interview with Gülen by a leading Russian Orientalist and advisor to the Russian president, Vitaly Naum- 


\section{The most direct and significant outcome of Russian-Turkish rapprochment was the Operation Olive Branch against the PYD, PKK's offshoot in Syria}

kin, was published in the Russian newspaper Moskovskii Komsomolets, perhaps demonstrating Russia's ability and willingness to accommodate and utilize both the PYD and the Gülenists against Turkey when deemed necessary for Russia's national interests. ${ }^{45}$

\section{Operation Euphrates Shield against ISIS, August 2016: A New Path Emerges}

The first and somewhat indirect consequence of Russian-Turkish rapprochment after the failed coup of July 2016 was the launching of Operation Euphrates Shield (OES) by Turkey against ISIS in August 24, 2016. ${ }^{46}$ Although Russia did not join this operation, it did not try to obstruct or prevent the operation from taking place either. Turkish Armed Forces (TAF) and the Free Syrian Army (FSA) liberated the the towns of Azaz in the west, Jarablus in the east, and Al$\mathrm{Bab}$ in the south, and the triangular territory in between, which also includes the towns of Marea and Dabiq. Dabiq had particular messianic eschatological significance for ISIS, because it emphasized a hadith identifying Dabiq as the location of an Armageddon-like major battle of apocalyptic significane at the end-of-times. ${ }^{47}$ Thus, by capturing this area including Dabiq, the TAF and the FSA dealt not only a strategic but also an ideological and psychological victory of religio-political significance over ISIS. ${ }^{48} \mathrm{OES}$ was the most important victory of the TAF-FSA partnership, militarily and politically, since the beginning of the Syrian Civil War. However, the territory of OES could not be sufficient to sustain a viable "Free Syria" for the millions of dissidents who opposed and were threatened by both the Assad regime and the PYD's Kurdish socialist oneparty regime. The next turning point in Russian-Turkish rapprochment, Operation Olive Branch, which will be discussed next, also had major consequences for the evolution and the expansion of the territory under FSA control.

\section{Operation Olive Branch against the PYD, January 2018: A Turning Point}

The most direct and significant outcome of Russian-Turkish rapprochment was the Operation Olive Branch (OOB) against the PYD, PKK's offshoot in Syria. PYD was "protected by Russia in the west and by the U.S. in the east" 49 of the Azaz-Jarablus-al Bab triangle demarcating the OES territory under FSA control with TAF support. In the west, Russia protected PYD in the Afrin pocket, whereas in the east, U.S. protected the PYD in the Manbij pocket west of Euphrates, as well as in a vast territory east of Euphrates extending from 
Tal Abyad and Raqqa in the west to Hasaka and Deir ez-Zor in the east. Unlike the United States, which continued to protect the PYD in Manbij despite years-long Turkish-American negotiations to evacuate Manbij and repeated promises not to allow PYD presence in the west of Euphrates, Russia agreed to allow the TAF and the FSA to conduct operations against the PYD in the Afrin region, with the exception of the strategically critical Tal Rifat pocket, which remains under PYD occupation to this day. ${ }^{50} \mathrm{OOB}$ was another positive turning point in Russian-Turkish relations, since Russia demonstrated a greater understanding of Turkish concerns and willingness to compromise in order to reach a sustainable negotiated solution in Syria that includes the FSA.

OOB was also a critical turning point connecting the two major regions controlled by the Syrian opposition under Turkish protection, namely, the OES triangle between Azaz, Jarablus, and al-Bab on the one hand, and the much larger and more populated Idlib province on the other. As a result, a relatively sizeable territory controlled by different factions of the Syrian opposition was established, extending from Jarablus and the OES region in the northeast to the Idlib province in the southwest, connected through Afrin and the OOB region in the middle. This was a momentous achievement in that the consolidation of sizeable and interconnected Syrian-opposition held pockets in northwestern Syria under Turkish protection could herald the construction of a provisional and truncated "Free Syria," albeit tucked in a small corner of the country and vastly overpopulated. Moreover, the Operation Peace Spring (OPS), which was undertaken as this article was being written, significantly expanded this territory by adding two major Arab-majority towns, namely, Tal Abyad and Ras al-Ayn, but these territories are not contiguous, as there is still PYD-SDF occupied Ayn al-Arab/Kobani in between Tal Abyad and Jarablus. Nonetheless, one must also recognize that this territory altogether (OES-OOB-OPS-Idlib) is still much smaller in size than the territorites held by the Assad regime under Russian-Iranian protection, and the PYD-SDF occupied territories in eastern Syria under U.S.-French protection. As such, the Assad regime and the PYD-SDF together control approximately 90 percent of Syria, splitting the territory in a roughly two-to-one ratio between them. Thus, any attempt to overcome the de facto disintegration of Syria has to confront and deal with the ever-deepening division of the country along the Euphrates river between two state-like structures patronized by Russia and Iran in the west, and France, and the U.S. in the east.

\section{Sochi Agreement and the Consolidation of the De-escalation Zones, September 2018}

If $\mathrm{OOB}$ was the crowning achievement of the Russian-Turkish rapprochement, the question of Idlib has been its biggest challenge to date. Perhaps because 
Idlib holds the potential as a rival center of power that could still challenge the legitimacy of the Damascus government, the Assad regime and its Iranian allies insisted on a final assault on Idlib. ${ }^{51}$ However, the crisis over the impending attack on Idlib was resolved with an agreement between Russian and Turkish presidents in Sochi in September 2018, reaffirming the role of Russia and Turkey as the guarantors of ceasefire and status quo in Syria, including Turkey's twelve military observation points around Idlib, which designate the de-escalation zone and the de facto borders of the Idlib region that should not be violated by Russia, Iran, or the Assad regime. ${ }^{52}$

The escalations around Idlib seem to be cyclical, and the most recent escalation occurred in April-June 2019, this time led by Russia, but these escalations did not yet alter

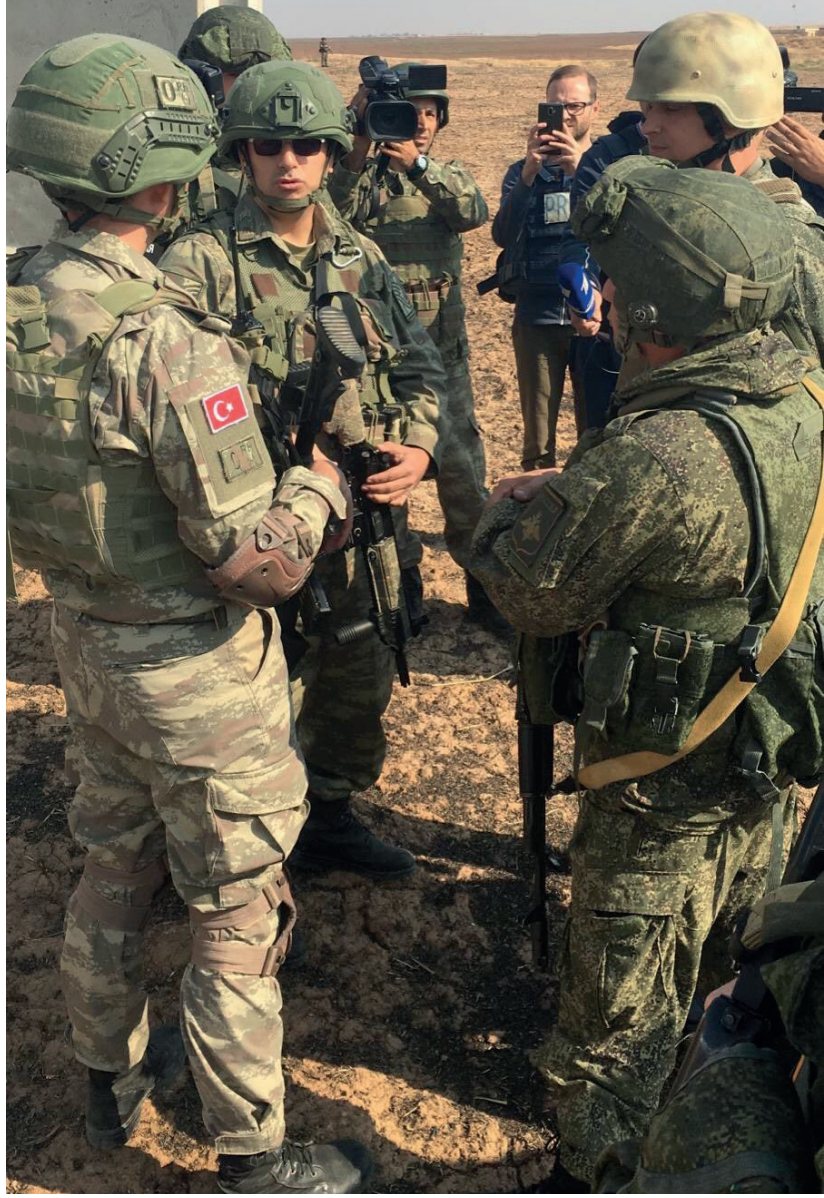

Turkish and Russian troops are seen after they started their first joint ground patrols in northern Syria on November 1, 2019.

Turkey's National Defence Ministry / Handout / AA Photo the de facto internal borders that the Turkish observation points and the de-escalation zone imply, ${ }^{53}$ with the notable exception of the Assad regime's offensive and the fall of Khan Sheikhoun, which led to the encirclement of Turkey's observation point in Morek, one of the twelve such observation points that Turkey established. ${ }^{54}$ The ability of Russia and Turkey to thwart major attempts to change the rough outlines of de-escalation zones in Syria is an encouraging sign insofar as it may eventually lead to a stable frozen conflict. However, multiple iterations of the violent escalation-de-escalation cycle do not yet seem to have produced a mutual understanding around freezing the military conflict for the foreseeable future in order to seek a political solution in the long run. It is nonetheless a worrying sign along these lines that from Russia's point of view, the "de-escalation zones," the perimeter of which is established by Turkey's observation points, "are merely a temporary measure," 55 implying that they expect the Damascus government to eventually take control of Idlib. Fortunately, whether in the Caucasus, Crimea, or Syria, Russia and Turkey managed to contain their potentially explosive differences of opinion and avoid any military conflagration since the end of the Cold War. 


\section{The changing balance of military-strategic threats has determined the course of Russian-Turkish relations both during and after the Cold War}

\section{Military Industrial Complications from the "Hegemon Rising" to the S-400 Imbroglio}

An important dimension of Russian-Turkish cooperation, which had already emerged in the 1990s and remains relevant to the present day, has been arms trade that involves military technology transfers. Some NATO member states such as Germany refused to sell arms to Turkey during Turkey's fight against the PKK in the 1990s, and even when arms sales were approved, military technology transfers were rare and very limited. Already in 1998, in an ominously titled article, "Hegemon Rising," published in the Parameters, the journal of the U.S. Army War College, Michael Robert Hickok wrote that the "Turkish military modernization is on the cusp of giving Turkey capabilities that far outstrip those of any single neighbor," and that these newfound capabilities coincide with "Ankara's experiment with post-Kemalist foreign policies," implying a concerted (military-strategic and ideological) effort at revisionism. ${ }^{56}$ As such, the fear of a potentially hegemonic Turkish military, almost certainly an exaggerated fear given Turkey's location at the intersection of the Balkans, the Caucasus, and the Middle East, three regions with numerous military powers that can withstand and balance Turkish power, already existed in the late 1990s, and thus preceded AK Party governments and/or Erdoğan as Turkey's chief executive.

Turkey's aspiration for an indigenous defense industry and a more self-sufficient military that can operate autonomously from the U.S. and the NATO alliance to pursue its own national interests alone if and when that becomes necessary are goals that go back at least to the Cyprus Peace Operation in 1974, if not even earlier. These aspirations are directly related to the Russian-Turkish rapprochement because Turkey has considered Russia as an alternative source of necessary military hardware and technology transfers, where the U.S. and the Western alliance appeared unwilling to supply. In that sense, the recent crisis between the U.S. and Turkey over the latter's acquisition of Russian S-400s is the latest but perhaps the most visible manifestation of Turkey's decades-long attempts to geopolitically diversify its military industrial portfolio. The fact that Turkey's frustration with the United States' refusal to sell Patriot missiles during the Syrian War led Turkey to buy S-400s from Russia was most recently publicly acknowledged by U.S. President Donald Trump himself during the G-20 summit in Osaka, Japan. ${ }^{57}$ As such, the S-400 imbroglio does not differ 
much in terms of its causes and trajectory from similar crises between Turkey and the United States in the 1960s (e.g., the Johnson letter), the 1970s (e.g., the Cyprus crisis), and the 1990s.

\section{Cross-Cutting Geopolitical Cleavages and Russian-Turkish Relations in a Multipolar World Order}

The intersection of domestic identity (linking subnational -ideological, ethnic, religious, sectarian, regional, etc.- and national) and geopolitical identity (linking supranational and national) contestation provides a multidimensional field of competition that includes ${ }^{58}$ but does not overdetermine foreign policy, including foreign economic strategy..$^{59}$ As the foregoing briefly indicates, it can be argued that the changing balance of military-strategic threats has determined the course of Russian-Turkish relations both during and after the Cold War. Perhaps of greater theoretical significance, increasing Russian-Turkish cooperation after the Cold War can be considered a harbinger of the transition from a unipolar to a multipolar world order, a transition that some leading Neorealist scholars such as John Mearsheimer consider as having taken place by $2016 .^{60} \mathrm{~A}$ multipolar world order is theoretically more prone to military conflicts, which makes it potentially more dangerous to live in. If the U.S.-Chinese competition becomes the primary geopolitical rivalry of this new multipolar world order as some scholars predicted long ago ${ }^{61}$ and some others still hope to avoid, ${ }^{62}$ then the relative positions Russia and Turkey assume vis- $\grave{a}$-vis the U.S.-Chinese rivalry will be of paramount importance for their bilateral relations as well as for the alliance structure of Eurasia at large.

\section{Endnotes}

1. Şener Aktürk, "Turkish-Russian Relations after the Cold War (1992-2002)," Turkish Studies, Vol. 7, No. 3 (2006), pp. 337-364.

2. Şener Aktürk, "Toward a Turkish-Russian Axis? Conflicts in Georgia, Syria, and Ukraine, and Cooperation over Nuclear Energy," Insight Turkey, Vol. 16, No. 4 (2014), pp. 13-22.

3. Şener Aktürk, "Türkiye'nin Rusya ile Illişkilerinin Yükselişi ve Gerilemesi [The Rise and Fall of Turkey's Relations with Russia]," in Gencer Özcan, Evren Balta, and Burç Beşgül (eds.), Kuşku ile Komşuluk: Türkiye ve Rusya Iliş̧kilerinde Değişen Dinamikler [A Neighborhood with Doubts: Changing Dynamics in Turkey and Russia's Relations], pp. 129-145, (İstanbul: İletişim Yayınları, 2017).

4. Şener Aktürk, "Why Did the PKK Declare Revolutionary People's War in July 2015?" Contemporary Turkish Politics, (2016), pp. 59-63.

5. Şener Aktürk, "Turkey's Role in the Arab Spring and the Syrian Conflict," Turkish Policy Quarterly, Vol. 15, No. 4 (2017), pp. 88-96.

6. Federico Donelli and Ariel Gonzalez-Levaggi, "Becoming Global Actor: The Turkish Agenda for the Global South," Rising Powers Quarterly, Vol. 1, No. 2 (2016), pp. 93-115.

7. Nurşin Ateşoğlu Güney, “New Russian Mahanism Failed: Futile Geopolitical Dreams in the Black Sea and Mediterranean," in Nurşin Ateşoğlu Güney (ed.), The New Geopolitical Realities for Russia: From the Black Sea to the Mediterranean, (UK: Lexington Books, 2019). 
8. Ziya Öniş and Şuhnaz Yılmaz, "Turkey and Russia in a Shifting Global Order: Cooperation, Conflict and Asymmetric Interdependence in a Turbulent Region," Third World Quarterly, Vol. 37, No. 1 (2016), pp. 71-95.

9. Seçkin Köstem, "When Can Idea Entrepreneurs Influence Foreign Policy? Explaining the Rise of the 'Turkic World' in Turkish Foreign Policy,' Foreign Policy Analysis, Vol. 13, No. 3 (2016), pp. 722-740.

10. Iver B. Neumann and Jennifer M. Welsh, "The Other in European Self-Definition: An Addendum to the Literature on International Society," Review of International Studies, Vol. 17, No. 4 (1991), pp. 327-348; Viatcheslav Morozov and Bahar Rumelili, "The External Constitution of European Identity: Russia and Turkey as Europe-makers," Cooperation and Conflict, Vol. 47, No. 1 (2012), pp. 28-48.

11. Duygu Bazoğlu Sezer, "Turkish-Russian Relations: The Challenges of Reconciling Geopolitical Competition with Economic Partnership," Turkish Studies, Vol. 1, No. 1 (2000), pp. 59-82.

12. Stephen K. Wegren and Alexander M. Nikulin, "Food and Foreign Policy," in Stephen K. Wegren (ed.), Putin's Russia: Past Imperfect, Future Uncertain, (7 ${ }^{\text {th }}$ ed.), (Lanham: Rowman \& Littlefield, 2019), p. 281.

13. "Russians' Disposable Incomes Are Falling: Quality of Life is Deteriorating for Ordinary People," Moscow Times, (April 23, 2019), retrieved from https://www.themoscowtimes.com/2019/04/23/ russians-disposable-incomes-are-falling-a65345.

14. Peter J. Katzenstein and Nicole Weygandt, "Mapping Eurasia in an Open World: How the Insularity of Russia's Geopolitical and Civilizational Approaches Limits Its Foreign Policies," Perspectives on Politics, Vol. 15, No. 2 (2017), pp. 428-442.

15. For more on this military-strategic argument in explaining Turkish-Russian relations based on changing balance of threats, see, Şener Aktürk, "Turkish-Russian Relations after the Cold War (1992-2002)."

16. Aktürk, "Turkish-Russian Relations after the Cold War," p. 357.

17. Aktürk, "Turkish-Russian Relations after the Cold War," p. 337. For more on this dynamic of radical vacillations in bilateral relations, see, Aktürk, "Türkiye'nin Rusya ile İlişkilerinin Yükselişi ve Gerilemesi."

18. For the special issue of the current journal on this topic, which was one of the first scholarly publications on the subject in English with contributions from numerous scholars, see, "July 15 Coup Attempt: People vs. Tanks," Insight Turkey, Vol. 18, No. 3 (Summer 2016); For a notable edited book with a dozen authors holding different views on the coup, see, Yavuz, M. Hakan and Bayram Balci, Turkey's July $15^{\text {th }}$ Coup: What Happened and Why, (Salt Lake City: University of Utah Press, 2018). See my critical review of this book, Şener Aktürk, "Turkey's July $15^{\text {th }}$ Coup: What Happened and Why," Insight Turkey, Vol. 21, No. 3 (2019), pp. 247-250.

19. Şener Aktürk, "Turkey's Civil Rights Movement and the Reactionary Coup: Segregation, Emancipation, and the Western Reaction," Insight Turkey, Vol. 18, No. 3 (2016), pp. 141-167.

20. Tuncay Kardaş and Ali Balcı, “Understanding the July 2016 Military Coup: The Contemporary Security Dilemma in Turkey," Digest of Middle East Studies, Vol. 28, No. 1 (2019), pp. 144-163.

21. For two exceptions, see, Aktürk, "Turkey's Role in the Arab Spring and the Syrian Conflict," and more recently Bezen Balamir Coşkun, "Turkey's Relations with Russia after the Failed Coup: A Friend in Need of a Friend Indeed?" New Middle Eastern Studies, Vol. 9, No. 1 (2019), pp. 36-52.

22. Ruslan Mamedovand and Grigory Lukyanov, "Russia and Turkey: Approaches to Regional Security in the Middle East," Perceptions: Journal of International Affairs, Vol. 23, No. 2 (2018), pp. 51-71.

23. Pavel Shlykov, "Russian-Turkish Relations in the Wider Black Sea Region: Cooperation and Competition," Perceptions: Journal of International Affairs, Vol. 23, No.2 (2018), pp. 93-116.

24. Ostap Kushnir, "Ukrainian Policies in the Black Sea Littoral: History, Current trends and Perspectives," Journal of Contemporary European Studies, Vol. 25, No.2 (2017), p. 175.

25. Şener Aktürk, "Türkiye-Rusya İlişkilerinde Yeni Dönem Mi? [A New Era in Turkish-Russian Relations?]," Sabah, (June 18, 2016), retrieved from https://www.sabah.com.tr/yazarlar/perspektif/sener-akturk/ 2016/06/18/turkiye-rusya-iliskilerinde-yeni-donem-mi.

26. See Aktürk, "Toward a Turkish-Russian Axis?"

27. Michael A. Reynolds, "Will Putin Be the 'Liberator Tsar' of the Kurds?" Newsweek, (March 20, 2016), retrieved from https://www.newsweek.com/putin-liberator-tsar-kurds-438453. 
28. Michael Doran and Michael A. Reynolds, "Turkey Has Legitimate Grievances against the U.S.," Wall Street Journal, (October 8, 2019), retrieved from https://www.wsj.com/articles/turkey-has-legitimategrievances-against-the-u-s-11570576128.

29. Reynolds, "Will Putin Be the 'Liberator Tsar' of the Kurds?"

30. Muhammed Boztepe, "Beşiktaş'taki Terör Saldırısını Düzenleyen Teröristlerden Biri Yakalandı [One of the Suspects of Terror Attacks in Beşiktaş Was Caught]," Anadolu Ajansı, (June 12, 2019), retrieved from https://www.aa.com.tr/tr/turkiye/besiktastaki-teror-saldirisini-duzenleyen-teroristlerden-biri-yakalandi/1502242.

31. “24 Temmuz 2015 Tarihinden İtibaren 7078 PKK'।ı Terörist Etkisiz Hale Getirildi [7,078 PKK Terrorists Have Been Neutralized Since July 25, 2015]," Hürriyet, (May 23, 2016), retrieved from http://www.hurriyet.com.tr/24-temmuz-2015-tarihinden-itibaren-7078-pkkli-terorist-etkisiz-hale-getirildi-37284748.

32. Aktürk, "Why Did the PKK Declare Revolutionary People's War in July 2015?"

33. Among numerous interviews, memoirs, books, articles, and hundreds of hours of TV programs demonstrating the almost unanimous belief among Turkish elites of different ideological convictions that the Gülenists are a fifth column cultivated by the United States for over three decades, see, the interview by the retired Admiral Cem Gürdeniz, who narrates the story of his imprisonment by the Gülenists for over three years in their concerted effort at taking over the Turkish Navy high command before the coup. Cansu Çamlıbel, “Emekli Tümamiral Cem Gürdeniz: Gülencilerle Mücadele Aczi 'Atlantik' Korkusundan [Retired Admiral Cem Gürdeniz: The Failure of Struggle against the Gulenists Is due to the Fear of 'Atlantic']," Hürriyet, (July 24, 2016), retrieved from http://www.hurriyet. com.tr/gundem/emekli-tumamiral-cem-gurdeniz-gulencilerle-mucadele-aczi-atlantik-korkusundan-ust-akil-roma-40167424.

34. Joe Lauria, "Reclusive Turkish Imam Criticizes Gaza Flotilla," The Wall Street Journal, (June 4, 2010), retrieved from https://www.wsj.com/articles/SB10001424052748704025304575284721280274694.

35. Fetullah Gülen, "Son Karakol [The Last Station]," Sızıntı, Vol.2, No. 21 (October 1, 1980); Republished in "Fethullah Gülen:"Darbeye Arz Ederim [I Offer to Stage a Coup]," Odatv, (August 14, 2010), retrieved from https://odatv.com/-fethullah-gulen-darbeye-arz-ederim--1408101200.html.

36. Nolan D. McCaskill, "Kerry: I Hope There Will be 'Stability, Peace, Continuity' within Turkey," Politico, (July 15, 2016), retrieved from https://www.politico.com/story/2016/07/john-kerry-turkey-coup-225632.

37. Richard Hass, Twitter, 12:20 AM, (July 16, 2016), retrieved from https://twitter.com/RichardHaass/ status/754063234131525632.

38. Şener Aktürk, Twitter, 10:10 PM, (July 16, 2016), retrieved from https://twitter.com/senerakturk/ status/754392754281644033.

39. Eliana Johnson and Shane Goldmacher, "Richard Haass under Consideration for State Department Deputy," Politico, (December 15, 2016), retrieved from https://www.politico.com/blogs/donald-trumpadministration/2016/12/richard-haass-state-department-deputy-232708.

40. For an earlier discussion by this author, see Şener Aktürk, "Turkey's Civil Rights Movement and the Reactionary Coup," Insight Turkey, Vol. 18, No. 3 (2016), pp. 141-167.

41. Fuad Safarov, "Rusya FETÖ'nün Tehlikeli Olduğunu Anlayan İlk Ülkelerden Biriydi [Russia Was One of the First Countries That Realized FETÖ Was a Threat]," Sputnik News, (August 4, 2016), retrieved from https://tr.sputniknews.com/columnists/201608041024222199-rusya-feto-turkiye-gulen/.

42. "Putin, Gülen İçin Uyardı [Putin Warned against Gulen]," Evrensel, (December 8, 2004), retrieved from https://www.evrensel.net/haber/156937/putin-gulen-icin-uyardi.

43. Among numerous news reports in this vein, i.e., "Robert Fisk: Rusya, Darbe Girişiminin Farkına Vardı, Putin, Erdoğan'a Mesaj Göndererek Uyardı [Robert Fisk: Russia Noticed the Coup Attempt, Putin Warned Erdoğan against It]," T24, (August 11, 2016), retrieved from https://t24.com.tr/haber/ robert-fisk-rusya-darbe-girisiminin-farkina-vardi-putin-erdogana-mesaj-gondererek-uyardi,354316.

44. “Darbe Girişimine Karşı Dünyadan Türkiye'ye Destek [Turkey Receives Support from all around the World against the Coup Attempt]," Anadolu Ajansı, (September 3, 2016), retrieved from https://www.aa. com.tr/tr/gunun-basliklari/darbe-girisimine-karsi-dunyadan-turkiyeye-destek/640160. 
45. "Rusya'dan Erdoğan'a Fethullah Gülen Golü [A Fetullah Gülen Trick from Russia to Erdoğan]," Odatv, (March 9, 2016), retrieved from https://odatv.com/rusyadan-erdogana-fethullah-gulen-golu0903161200.html; “Gülen: Rus Uçağının Düşürülmesi Yanlıştı [Downing of the Russian Fighter Jet Was Wrong],"Internet Haber, (March 10, 2016), retrieved from https://www.internethaber.com/gulen-rus-ucaginin-dusurulmesi-yanlisti-1573453h.htm.

46. Murat Yeşiltaş, Merve Seren, and Necdet Özçelik, "Operation Euphrates Shield: Implementation and Lessons Learned," SETA, (2017), retrieved from https://setav.org/en/assets/uploads/2017/11/R97_Euphrates.pdf.

47. David Patrikarakos, "Apocalypse or Bust: The Battle for Dabiq," Radio Free Europe Radio Liberty, (October 9, 2016), retrieved from https://www.rferl.org/a/tracking-islamic-state-dabiq-battle-apocalypticism/28040703.html.

48. Yeşiltaş, Seren, and Özçelik, "Operation Euphrates Shield," pp.14, 28.

49. Yeşiltaş, Seren, and Özçelik, "Operation Euphrates Shield," p. 51.

50. Necdet Özçelik and Can Acun, "Terörle Mücadelede Yeni Safha: Zeytin Dalı Harekatı [A New Phase in the Fight Against Terror: Olive Branch Operation]," SETA, (2018).

51. Charles Lister, "The Urgency of Idlib:The Impending Regime Offensive and the Delicate Balance in Syria's Northwest," War on the Rocks, (August 3, 2018), retrieved from https://warontherocks.com/2018/08/ the-urgency-of-idlib-the-impending-regime-offensive-and-the-delicate-balance-in-syrias-northwest/.

52. Şener Aktürk, "Soçi Uzlaşması Özgür Suriye ve Türkiye İçin Önemli Bir Kazanım [Sochi Agreement Is a Significant Win for Free Syria and Turkey]," Sabah, (September 22, 2018), retrieved from https://www. sabah.com.tr/yazarlar/perspektif/sener-akturk/2018/09/22/soci-uzlasmasi-ozgur-suriye-ve-turkiye-icinonemli-bir-kazanim.

53. Paul McLoughlin, "Syria Weekly: Idlib Offensive Stalls, as Russia-Iran Divisions Bubble over," The New Arab, (June 28, 2019), retrieved from https://www.alaraby.co.uk/english/indepth/2019/6/28/syriaweekly-idlib-offensive-stalls-as-russia-iran-rivalry-continues.

54. Dominic Evans, "Syrian Offensive Puts Turkish Troops and Border Plans in Peril," Reuters, (August 22, 2019), retrieved from https://www.reuters.com/article/us-syria-security-turkey/syrian-offensive-putsturkish-troops-and-border-plans-in-peril-idUSKCN1VC1PA.

55. Mamedov and Lukyanov, "Russia and Turkey," p. 62.

56. Michael Robert Hickok, "Hegemon Rising: The Gap between Turkish Strategy and Military Modernization," Parameters, Vol. 30, No. 2 (2000), pp. 105-119.

57. "NATO Member Turkey Not Treated Fairly: Trump on S-400 Deal," TRT World, (June 29, 2019), retrieved from https://www.trtworld.com/asia/nato-member-turkey-not-treated-fairly-trump-on-s-400deal-27882.

58. Ali Balcı, Dış Politikada Hesaplaşmak: AK Parti, Ordu ve Kemalizm [Confronting through Foreign Policy: AK Party, Military and Kemalism], (İstanbul: Etkileşim, 2015).

59. Seçkin Köstem, "Different Paths to Regional Hegemony: National Identity Contestation and Foreign Economic Strategy in Russia and Turkey," Review of International Political Economy, Vol. 25, No. 5 (2018), pp. 726-752.

60. John J. Mearsheimer, "Bound to Fail: The Rise and Fall of the Liberal International Order," International Security, Vol. 43, No. 4 (2019), pp. 7-50.

61. John J. Mearsheimer, The Tragedy of Great Power Politics, (New York: W. W. Norton \& Company, 2001).

62. Stephen Wertheim, "Is It Too Late to Stop a New Cold War with China?" The New York Times, (June 8, 2019), retrieved from https://www.nytimes.com/2019/06/08/opinion/sunday/trump-china-cold-war. html. 
